\title{
Violencia y multiplicidad narrativa en Bioy, de Diego Trelles Paz*
}

\section{Violence and narrative multiplicity in Bioy, by Diego Trelles Paz}

\section{Resumen}

En este artículo se estudia la violencia en la novela Bioy (2012), de Diego Trelles Paz, a través de dos ejes: el tiempo y las voces narrativas. Ambos vertebran un relato caracterizado por su multiplicidad narrativa, que se correlaciona con la complejidad de la violencia que el texto explora, emanada del Perú de finales del siglo XX y comienzos del XXI. Se pretende dilucidar las coordenadas de la violencia en el texto merced a los dos ejes mencionados.

Palabras claves

Bioy; Diego Trelles Paz; violencia; narración.

\begin{abstract}
This article presents a study about violence in the novel Bioy (2012), by Diego Trelles Paz, by means of two axes: time and narrative voices. Both structure a narration characterised by its narrative multiplicity, correlated with the complexity of the violence that the text explores, emerged from Peru at the end of the 20th century and beginning of the 21st century. The aim is to elucidate the coordinates of the violence in the text through the two mentioned axes.
\end{abstract}

Keywords

Bioy; Diego Trelles Paz; violence; narrative.

* Este trabajo se ha llevado a cabo gracias al programa de Ayudas para la Formación de Profesorado Universitario (FPU15/05737), del Ministerio de Educación, Cultura y Deporte del Gobierno de España. 


\section{Introducción}

Son varios los estudios que en los últimos tiempos han explorado la violencia en Perú de décadas recientes con relación a la literatura ${ }^{1} \mathrm{u}$ otros modos de representación ${ }^{2}$, hasta constituir una línea de investigación fructífera que se mueve entre el texto y la sociedad a la que se refiere. Ha aclarado ello las trazas de un panorama complejo donde abundan autores que apenas han sido aún objeto de trabajo crítico o siquiera de lectura más allá de las fronteras del Estado peruano, como lamentaba Gnutzmann:

A pesar de que hoy día, gracias a autores como Julio Ramón Ribeyro, José María Arguedas, Mario Vargas Llosa y Alfredo Bryce Echenique, la literatura peruana en modo alguno puede ser considerada "pobre" ni “desconocida", los escritores de las últimas dos décadas apenas han podido penetrar en el mercado internacional e incluso han conocido dificultades para obtener el debido espacio en el mundo editorial limeño, como ilustra la novela Candela quema luceros de Félix Huaman [sic] Cabrera, publicada en 1989 (ed. Retama), pero inaccesible para el gran público hasta su nueva edición por la Editorial San Marcos en 2003. Aunque es cierto que en España hay excepciones como Fernando Iwasaki, Jorge Eduardo Benavides y Santiago Roncagliolo - seguramente por su cercanía al mundo editorial de su país de acogida - aparte de Alonso Cueto, ganador del Premio Herralde en 2005 y el incansable Jaime Bayly, no se han publicado los textos de Miguel Gutiérrez, E. Rivera Martínez, Laura Riesco, Pilar Dughi, L. Nieto Degregori, Zein Zorrilla, Óscar Colchado, E. Rosas Paravicino, Sandro Bossio, Siu Kam Wen, etc. La

\footnotetext{
${ }^{1}$ Sirva como ejemplo Sourp, que estudia la violencia en la escritura de Mario Vargas Llosa.

2 Por ejemplo, el cine en Gnutzmann ("Cine y novela").
} 
mayoría de ellos han dedicado parte de su obra al tema de la violencia de los últimos lustros del siglo XX. (“Cine y novela” 69)

Apuntaba esta estudiosa a varias generaciones de escritores peruanos anteriores a Diego Trelles Paz, pero su juicio puede extenderse a este, quien solo lentamente se está haciendo un hueco en el ámbito internacional, lo cual se traduce en una creciente cantidad de lectores y en su conocimiento más allá de las fronteras peruanas $^{3}$. A ello han contribuido dos premios importantes, a los que accedió con la novela que estudiamos ahora: Bioy (2012). Se trata del Premio Francisco Casavella (2012), el cual obtuvo, y el Rómulo Gallegos (2013), en el cual resultó finalista.

Bioy es una novela cargada de complejidades formales $-\mathrm{y}$ continuas novedades en este plano-, a las cuales es preciso aludir para descifrar el tratamiento que da a la violencia peruana. Ya en su arranque se desvela su presencia como clave compositiva: “Cómo se narra el horror si es más poderoso que cualquiera de mis palabras? ¿Cómo se nombra lo que duele imaginar? Mejor detenerse, soltar el lápiz, negar" (Bioy 11). En esta cita se aúnan el horror y, por otro lado, el interés por tantear el modo de decirlo y de narrarlo, con el trasfondo de la violencia como generadora de ese horror.

Horror y violencia, así, son caras de la misma moneda en Bioy, y esto anuncia una peculiar conexión con la realidad peruana que conforma la base en la que se ambienta su trama narrativa. En particular, acoge el conflicto político y

${ }^{3}$ Solo he localizado dos trabajos orientados de modo monográfico a Trelles Paz: Gocławska y Almenara. Gocławska se aproxima a su novela Bioy desde una herramienta teórica concreta: el pensamiento de Slavoj Žižek. Su interés se centra en las relaciones de dominio entre los personajes, en especial el papel de la sexualidad en este entramado. Almenara afronta cuestiones específicas de la masculinidad en la misma novela. De igual forma, tengo en consideración los acercamientos de Trelles Paz a su propia obra. Particularmente, de Bioy se ocupa en una contribución a un volumen colectivo dedicado a la violencia en las narrativas de América Latina ("Bioy o la escritura"). Entre trabajos generales que lo nombran, aun tangencialmente, cabe mencionar a Forero Quintero y una monografía sobre la "novela de crímenes" en América Latina (La novela de crímenes 193-220). He conocido, después de haber mandado este artículo para su publicación, entre otras, una aportación de Morales-Muñoz que recojo en la bibliografía final y que, por motivos obvios, no pude aprovechar para la preparación del artículo. 
social que agitó al Estado peruano durante un par de décadas al menos, con la incursión de un partido político que comenzó su actividad allá por 1980, promovido por Abimael Guzmán Reynoso o Reinoso ${ }^{4}$, profesor de la Universidad de Huamanga: el Partido Comunista del Perú-Sendero Luminoso (PCP-SL). Tanto Guzmán como Sendero Luminoso — que es como lo nombraré en lo sucesivoconfiaron en la violencia, el horror y el terrorismo como motor del cambio en Perú y como tal los aplicaron. En 2003, desde instancias oficiales, se creó la Comisión de la Verdad y Reconciliación, encargada de pasar balance al conflicto, cuyo "Informe final" dedica una notable importancia a esta organización 5 .

La literatura, como es de esperar, no se ha mantenido ajena a todo ello y Sendero Luminoso se ha integrado en recientes novelas - entre otros géneros - de autores nacidos en Perú, como es Trelles Paz Roncagliolo; Un lugar llamado Oreja de Perro (2008), de Iván Thays, etc. Un antecedente de primer orden es Lituma en los Andes (1993), de Mario Vargas Llosa $^{7}$. En lo que respecta a Bioy, en el marco de los múltiples tratamientos que se le podría dar a la violencia y en vista de los trabajos que preceden a este - antes citados - es pertinente adentrarse en cuestiones de tipo formal, como son el tiempo y las voces narrativas. Ambas instancias canalizan la violencia, y por tanto el fin de este análisis no es otro que el de arrojar luz sobre las coordenadas en que la novela la perfila a partir de estos dos componentes. Podrían destacarse otros, pero estos resultan valiosos.

${ }^{4}$ Existe vacilación a la hora de citar su segundo apellido.

5 Puede consultarse el "Informe final" en la página web de la Comisión de la Verdad y Reconciliación. Dado que la bibliografía sobre Sendero Luminoso abunda, puede verse, por ejemplo, un trabajo de Carlos Iván Degregori donde aborda los principios de la organización. Recientemente, ha aparecido Ríos y Sánchez.

${ }^{6}$ Sobre Sendero Luminoso en la reciente literatura peruana, véanse, entre otros, Gnutzmann ("Cine y novela" y "Una retrospectiva"), Noemí, Llano, Vivanco, Amar Sánchez y Cuya Gavilano.

${ }^{7}$ La relación literaria entre Vargas Llosa y Trelles Paz fue advertida de inmediato: "Si Vargas Llosa tuviera treinta años y sus orígenes fueran otros, pero la potencia narrativa la misma, podría haber firmado este libro: La ciudad y los perros 2.0" (Gabi Martínez apud ElCultural.es) 


\section{EI tiempo}

Como las voces narrativas, el tiempo obliga a repasar la trama. Por medio de la dialéctica entre el pasado (1986) y el futuro (2002-2008), referidos desde el presente (2012), se exploran los pormenores de una violación y la venganza perpetrada años más tarde por Marcos Abraham Fernández Olmos, un joven cuya principal aspiración reside en asesinar a los responsables de esa violación, cuya víctima fue Elsa Carhuayo. Tuvo lugar en 1986 y es el detonante de la trama. La violación formó parte de la tortura a la cual fue sometida Elsa por su conexión con Sendero Luminoso, y los ejecutores fueron cuatro militares del Ejército del Perú: Sergio Gómez, el suboficial Ricardo Franco — el Bembón Franco_-, el mayor — cuyo nombre completo no se desvela y después se dice que en el exilio se hará llamar Eduardo Noriega y que su apellido original es Bustamante- y un cabo de "No más de veinte" (Bioy 31) años en fase de aprendizaje: Bioy Cáceres. Mientras que los tres anteriores se regocijan con la violación y su sadismo, el cabo Bioy se siente incómodo. Llega a ayudar a Elsa en un baño, lo cual desata la ira de sus compañeros y también superiores (Bioy 12-13), que ponen en tela de juicio su virilidad y su heterosexualidad ${ }^{8}$. La novela arranca in medias res y consigue así esbozar desde el primer momento el frágil estado de Elsa:

Enferma, hambrienta, delirante. Asqueada hasta la náusea por el olor de su propia mierda. Los pantalones hediondos pegados a la piel. Las piernas laxas contraídas contra el abdomen en posición fetal. El torso desnudo y tembloroso bajo una toalla sucia y, entre sus antebrazos, coloreados por hematomas, los pechos robustos cuelgan de lado, aún melosos por el rastro de esperma.

Ya ha sido violada. Una vez. (Bioy 11)

\footnotetext{
${ }^{8}$ En otros puntos, la heterosexualidad regresará como motivo problemático en torno a Bioy Cáceres (Bioy 153), como ha visto Almenara (162).
} 
La primera parte, llamada sin más "Uno" ", aglutina la violación contra Elsa y todo lo que la rodea (1986) y la complementa, en continuo vaivén, con los sucesos acaecidos en el comienzo del siglo XXI (2002-2004). Se imbrican ambas tendencias a través de una intercalación de capítulos -1986, 2002, 1986, 2003, 1986, 2004 y 1986 - con la cual mostrar variedad narrativa y abrir una dialéctica entre los dos grupos de años, cuya contraposición resultará importante. Respecto a 1986, el texto busca la detención del tiempo en la sala de torturas, una cocina, donde los cuatro militares forzaron a Elsa, hecho visible en que este año se mantiene invariable pese a las alternancias y las intercalaciones en relación con los tres años del siglo XXI. Esta violencia, proyectada en el tiempo, solo engendrará más violencia, como se trasluce en las muertes que se suceden en el otro grupo de años: Gómez (2002), Franco (2003) y el mayor (2004). Marcos se sincerará ante Elsa tiempo después: “-A los milicos, a los tres hijos de puta que te violaron: ¡Fui yo!... Gómez, Franco, Bustamante: yo los asesiné y no me arrepiento, ¿ok? ¡No me arrepiento ni un poquito!... Lo hice por ti, mamá. Lo hice por nosotros" (Bioy 201). El joven calcula las muertes de sus víctimas con extremo cuidado y siente así que, de algún modo, devuelve a los militares el daño que hicieron a Elsa. El tiempo de Elsa no escapa de 1986, el de Marcos progresa pero con atención a 1986.

Sin embargo, ¿qué une a Marcos con 1986? ¿Por qué esa voluntad de castigar a los militares? La respuesta debe buscarse en una certeza suya, y solamente suya: que nació como fruto de aquella violación, con lo cual su madre sería Elsa Carhuayo. Pero su planteamiento va más allá: considera también que su padre es el cabo Cáceres. Esto último resulta factible si tenemos en cuenta que este, finalmente, intervino en la violación por insistencia de sus compañeros (Bioy 88), aunque su agresión se sugiere por elipsis, en lo que es un momento crucial de "Uno". La violación supone también un punto de inflexión en su psicología, que diferirá radicalmente en las demás partes del libro. No por casualidad en este

\footnotetext{
${ }^{9}$ Se compone de cuatro: respectivamente, "Uno", "Dos", "Tres" y "Cuatro", a las cuales me referiré por estos nombres. No deja de ser llamativo que sean cuatro, como cuatro son los torturadores de Elsa. Se produce una cierta armonía estructural en torno a esta cifra.
} 
momento por primera vez se hará llamar por el nombre que lo caracterizará en el futuro, sin cargos o apellidos que lo precisen: Bioy. Así se manifiesta en un acto de rebeldía esencial ante Ricardo Franco:

—Cabo Cáceres, ¿qué espera? —interroga el suboficial Franco [...].

—Bioy... — contesta de pronto el cabo con frialdad, sin levantar la mirada, con una rara palabra que suena extranjera.

—i¿Qué mierda has dicho?! —interviene Gómez, curioso, incrédulo, harto ya de toda la situación.

- He dicho Bioy, mi capitán. Mi nombre... Sólo he dicho mi nombre. Se levanta el muchacho de golpe y, mientras manipula con displicencia la hebilla de su correa, como en una procesión personal, se dirige lenta y resignadamente hacia la mujer. (Bioy 87-88)

El Bioy que se avecina tras la agresión sexual hará de la violencia una de sus señas de identidad, la cual le permitirá abrirse paso en una sociedad donde se sirve de ella para mediar en sus relaciones sociales y acabar transformándose en el jefe de "una de las bandas más poderosas y sanguinarias de la ciudad de Lima" (Bioy 97), como se apunta en "Dos".

Sin embargo, ¿por qué Bioy? ¿Qué hace pensar a Marcos que de los cuatro violadores este es su padre? La hipótesis — tesis irrefutable para Marcos- se despejará en el transcurso del relato, gracias al encadenamiento de distintos hechos que harán imposible esta conexión. Ello no obsta para que el lector se sienta confuso ante el razonamiento del joven e incluso pueda estimar su hipótesis como cierta durante gran parte de la novela. Desde mi punto de vista, el origen de la creencia debe rastrearse en la violencia de Bioy y la admiración del joven hacia él por esta causa; no solo por la violencia que directamente lo implica, sino también por la que propicia en razón de sus actividades mafiosas en Lima. Marcos establece así como figura paterna a un modelo de conducta para él y a alguien al cual, en última instancia, espera derrotar. La vía para ello es el asesinato, con el cual imponer su 
violencia a la de él y acabar de vengar a su "madre". Esa es la forma de superar al padre. La novela se puede leer como una dialéctica entre Marcos y Bioy que se sustenta en la tentativa del primero por imponerse al segundo.

Caso distinto es el de Elsa. Marcos ve en ella a su madre por una circunstancia fortuita que explica María de Jesús Olmos de Fernández, abuela de Marcos, en "Cuatro":

El peor error de mi vida llegó cuando cumplió quince. Yo tenía en el baúl de mi cuarto, ocultos dentro de un libro de cocina Nicolini, dos fotos de Myrna y un recorte de periódico que tontamente había conservado porque hablaba de Elsa Carhuayo. ¿Se acuerda usted de Elsita, señor? ¿La niña que se quedaba en casa? ¿Esa que era buenita? Pues bien, nunca entendí cómo, pero un día abro un periódico y ¿qué cree?: ¡ahí estaba la muchachita! Yo la pensaba muerta como todo el resto, pero no. ¡Imagínese! Era para no creerlo. Elsa estaba viva pero loca, la pobre chica se había vuelto completamente loca. La habían internado en Larco Herrera y ahí, que yo sepa, se ha quedado hasta el día de hoy. No sé cómo se las ingenió Marcos para abrir mi baúl. Tenía doble candado y el muchacho del demonio los abrió sin romperlos. Cuando encontró las fotos junto al recorte, por el parecido físico entre ambas sin duda, mi nieto pensó que Myrna y Elsa eran la misma persona. Creyó que por fin había encontrado a su madre y, sin decirme nada, sin siquiera reclamarme, salió a buscarla. (Bioy 274-275)

Fue la curiosidad la que hizo tropezar al joven con unos recortes de prensa sobre Elsa. De ahí infiere una filiación familiar equivocada. Se distingue esta identificación de la de Bioy, pero en ambos radican según Marcos sus orígenes familiares. El pasado da así un fruto confuso en los años posteriores.

Del mismo modo, el episodio incide en la caracterización de Marcos. Primero, viene a reforzar su imagen tenaz, debido a que llega a desbaratar el doble 
candado del baúl, tal como figura en el fragmento anterior. Segundo, su auténtica madre es Myrna y Elsa una compañera suya en las actividades de Sendero Luminoso. Si María de Jesús guardó esos recortes de prensa no fue sino por el cariño que profesaba a Elsa.

Mueve a Marcos, por consiguiente, una causa equivocada, pero ello no obsta para que se alce como personaje importante, si bien no el principal, a mi modo de ver. La novela sitúa en esa posición a Bioy, al original cabo Cáceres, por tres motivos que le hacen imponerse a los demás personajes: a) con Elsa, es el único presente en la violación de 1986 que aguanta con vida durante la mayor parte de la novela, lo cual lo convierte en representante del lado del victimario frente a Elsa, víctima; son dos enlaces directos a aquella agresión; b) Bioy es el objetivo de Marcos, con lo cual este segundo en cierto modo se supedita a él, y c) es el personaje de evolución psicológica más compleja. Bioy participa en casi todas las partes, como Marcos; solo se ausentan de una:
a) Bioy: "Uno", "Dos" y "Cuatro"
b) Marcos: "Uno", "Tres" y "Cuatro"

Ambos coincidirán en la primera y la última, parámetro estructural sintomático del cierre de la novela ${ }^{10}$.

"Dos" se atiene a un tiempo diferente de "Uno" y se rige por principios narrativos alternativos. Contra el vaivén de la primera parte, "Dos" alberga un relato uniforme y continuado - dentro de lo que es Bioy-, pues cuenta con nueve capítulos que se suceden en un sentido de trama y de tiempo, enumerados del "1" al “9”. Estos recogen la infiltración de un agente de la Policía Nacional del Perú en la banda de Bioy para recabar datos de ellos y de Natalio Correa, un narcotraficante

\footnotetext{
${ }^{10}$ Otro consiste en la disposición de los paratextos que anteceden a cada parte, extraídos de Todos los hermosos caballos, de Cormac McCarthy ("Uno"); Escrito a ciegas, de Martín Adán ("Dos"); El desbarrancadero, de Fernando Vallejo ("Tres"), y Meridiano de sangre, de Cormac McCarthy ("Cuatro"). El mismo autor abre y cierra la serie, y este, McCarthy, es de origen estadounidense, en tanto que los del medio son de origen hispanoamericano. Se acotan así dos geografías importantes para la novela, como después veremos.
} 
mexicano que colabora con la banda y es muy buscado por los servicios de seguridad peruanos. El agente se llama Humberto Rosendo Hernández y la perspectiva de estos nueve capítulos será la suya, nacida de su experiencia personal. $\mathrm{Si}$ al principio una cita ponía de relieve la dificultad de narrar el horror (Bioy 11), comprobamos ahora que la noción toma forma en las modulaciones propias de la construcción del relato:

Bioy.

Su mirada, su silencio, su lenta furia.

Lo imagino ahora y la incertidumbre regresa con las mismas preguntas: ¿cómo describirlo sin sentir que me equivoco? ¿Qué hacer con los adjetivos cuando suenan a poco, cuando su poder y su color y todo su ornamento se vuelvo hueco y uno no puede dejar de sentirse un embustero intentando capturar algo que está siempre en movimiento? La realidad es más rápida y astuta y horrible que la imaginación. (Bioy 106)

Pese a que la vida de este agente de policía peligrará en no pocas ocasiones, por diversos motivos, su perspectiva aguantará en los mencionados capítulos, contextualizados entre 2007 y 2008. Se elabora así un relato que dista de la temporalidad múltiple de "Uno", al componerse de capítulos que cooperan en este sentido. De ellos, además, pueden precisarse datos más concretos que el año. El marco temporal general se deduce con facilidad de la literalidad del texto, a tenor de una primera cita: "Mi primer contacto con Martillo ocurrió el 13 de julio del 2007 en las inmediaciones del bar Caín en el Cercado de Lima. No tiene sentido recordar el arduo proceso que significó acercarme" (Bioy 100). Y una segunda:

Estoy por cumplir seis meses de infiltrado en la banda de Bioy y ahora mismo me doy cuenta de que he perdido por completo la perspectiva. No tengo contacto con mi esposa, no veo a mis hijos. Por su seguridad, estoy absolutamente prohibido de acercarme a casa. Para ellos, soy la escolta 
principal del embajador peruano en Japón y estoy en misión secreta. Todas las semanas los llamo por teléfono y les juro llorando que esto acabará pronto. No me creen. (Bioy 95)

El capítulo más sencillo de fechar es "9", que se inicia con los datos pertinentes: "Lima, 5 de mayo, 2008" (Bioy 165). Con ellos, puede datarse la conclusión de "Dos", erigida en la parte más cohesionada del relato, reforzada por la firma del protagonista y narrador, que viene a reforzar su unidad como historia de un personaje concreto contada por quien la vivió:

\section{Humberto Rosendo Hernández}

Agente PNP

Dirección de Inteligencia (DIRIN)

DNI. 09884573 (Bioy 167)

"Tres" recupera artificios formales de "Uno", pero lo supera en meticulosidad: asigna día y mes a cada uno de los capítulos, encuadrados en tiempos alternativos. Se produce de este modo un contraste profundo con "Dos".

La particularidad de "Tres" sobre "Uno" reside en que el tiempo no marca el vaivén entre los capítulos, sino que tal función es asumida por la multiplicidad de cauces narrativos - el tiempo solo los contextualiza - Son tres: a) el blog $L a$ gente es fea, cuyas entradas se fechan entre el 4 de febrero y el 1 de julio de $2008^{11}$; b) el hospital Víctor Larco Herrera, entre febrero y abril de 2008, y c) un Cuaderno de pensamientos y estrategias, escrito entre noviembre de 2001 y agosto de 2002. Cada bloque luce una tipografía diferente, lo cual abunda en sus diferencias.

Las fechas de cada capítulo son las siguientes, según el cauce correspondiente ${ }^{12}$ :

${ }^{11}$ En Bioy suele ser sencilla la datación de los acontecimientos centrales de la trama, dado que suelen pautarse por medio de año, mes, día u hora. Se utiliza así el tiempo para tensar la intriga y, de paso, ayuda en la ordenación de la materia narrativa, diseminada como está.

${ }^{12}$ Compleméntese con lo expuesto en la Tabla 1, más abajo. 
a) "La gente es fea"

i) 4 de febrero de 2008

ii) 8 de febrero de 2008

iii) 12 de febrero de 2008 (comentario: 7:05 del 4 de febrero de 2008)

iv) 20 de febrero de 2008 (comentarios: 7:05 del 20 de febrero de 2008, 22 de febrero de 2008 y 21 de febrero de $2008^{13}$ )

v) 1 de marzo de 2008 (comentario: 7:05 del 1 de marzo de 2008)

vi) 6 de abril de 2008 (comentario: 7:05 del 6 de abril de 2018)

vii) 1 de julio de 2008

b) "Hospital Víctor Larco Herrera"

i) $11: 30$, febrero de 2003

ii) 18:00, junio de 2004

iii) 9:05, enero de 2007

iv) 2:00, marzo de 2007

v) 00:05, abril de 2008

c) "Cuaderno de pensamientos y estrategias"

i) Noviembre de 2001

ii) Marzo de 2002 y 1 de agosto de 2002

${ }^{13}$ Aquí, curiosamente, se recogen tres comentarios de los "4 Comments" (Bioy 198) anunciados, es decir, se elide uno. Ello abunda en la idea de síntesis y selección que caracteriza a toda la novela. Se narra lo fundamental, con abundantes vacíos en el relato. Es una novela especialmente abierta a la cooperación con el lector. 
Tres canales que ejercen de fuente de situaciones narrativas individualizadas que deben vincularse en la búsqueda de un plano general de "Tres", incluso en lo relativo al blog, lejano en apariencia del conflicto central de Bioy. Pero no: de la misma manera que los capítulos referidos al blog presentan continuidad, la mantienen en relación con el total de la novela. La razón es que Eme Zunz, Diegoulasse el Exterminador y Damián el Joto, las tres identidades virtuales principales del blog, convergen en una identidad única, Marcos, como se dilucidará en la cuarta parte (Bioy 256). Asistimos en este punto a un nuevo divertimento de Marcos, que crea tres heterónimos para manifestarse en el blog que él mismo diseña.

De igual forma, Marcos recopila abstracciones e inquietudes en su Cuaderno de pensamientos y estrategias. Disemina por sus páginas datos fundamentales que aclaran lugares oscuros de la novela o, sencillamente, lugares abiertos a más información, esenciales todos ellos para una visión global de Bioy. Por ejemplo, muestra en su Cuaderno un cuadro clínico personal (Bioy 215) que denota un grave trastorno de personalidad o señala detalles del asesinato de Sergio Gómez (Bioy 215), ejecutado con dosis de sadismo en las que se recrea, orgulloso como está de su "sangre fría a la hora de eliminarlo" (Bioy 215) y de que "Sergio Gómez murió sufriendo" (Bioy 215) ${ }^{14}$.

El blog y el Cuaderno se entreveran con los pasajes de Elsa en el hospital, donde está internada y vive detenida en el pasado, en gran medida por la violación. Sucesos traumáticos de distinto tipo se agregan a este, que giran en torno a Sendero Luminoso. Profunda huella le dejó la muerte en 1991 de quien era su pareja: Abel, o "camarada Leoncio" al frente de las actividades terroristas. Elsa no asume su muerte y tampoco el tiempo pasado desde entonces; los tiempos se confunden en su mente, tan distorsionada como su lenguaje:

—iAbel-Abelito?

${ }^{14}$ Nótese la diferencia con la incomodidad del cabo Cáceres ante la violencia que tenía por objeto a Elsa en 1986. 
— ¡Noooo!...

— ¿Claro que sí! Abel-Abelito vive vive vive vive vive vive...

—No, mamá, NO: Abel Hurtado, el camarada Leoncio, murió en el año noventa y uno. Lo ejecutaron junto a trece personas y un niño en una pollada en Barrios Altos. Te lo he dicho antes, mamá. ¡Te lo he dicho mil veces! ¿Qué quieres? ¿Que te mienta? (Bioy 201)

Lo anterior se lo dice a Marcos, quien la visita pese a no poder acreditar su supuesta relación maternofilial. A causa de ello, es amonestado en varias ocasiones, pero sin consecuencia alguna (Bioy 218). Ni las amenazas de la enfermera le hacen vacilar (Bioy 220-221). Elsa no acierta siquiera con la identidad de su interlocutor: “- Cuéntame otra vez la historia de tu padre, Tomasito, el marido de la loca AbelAbelito para que la escuche don Ramiro el viejo furifuri no me cree ni los rezos pero a ti sí” (Bioy 199).

En definitiva, "Tres" funciona como un collage que debe escrutarse con cuidado para unir las piezas que lo componen, tal como ocurre con la novela en general. Solo habrá una dificultad insalvable: en La gente es fea se menciona el día exacto de cada entrada y de los comentarios a los que ha dado pie, lo cual no se repite en las otras dos secciones, "Hospital Víctor Larco Herrera y "Cuaderno de pensamientos y estrategias", donde se nombran el mes y el año y en el primero la hora. Pero estos datos sin el día no nos sirven de mucho a nuestros efectos, con lo cual quedamos relegados al terreno de las hipótesis, una vez más. Por ejemplo, una entrada al blog se fecha a 6 de abril de 2008 y Marcos rinde visita a Elsa en abril de 2008. ¿El mismo día? Imposible de dilucidar.

Solo una alusión más al tiempo en "Tres". Existe una circunstancia problemática referente al blog: cuatro comentarios se cargan a la misma hora en días distintos, las 7:05. Sus autores son, sucesivamente, Diegoulasse el Exterminador, Damián el Joto, Diegoulasse el Exterminador y Larrita. Subraya ello 
la exhaustividad del joven también en la Red, capaz de pautar sus movimientos al detalle $^{15}$.

Para acabar este recorrido, "Cuatro" se vertebra merced a un nuevo vaivén: ahora de dos series de episodios. El mecanismo retoma el funcionamiento de "Uno", pero media un matiz: el tiempo no pauta la alternancia, sino que se limita a enmarcarla. En "Cuatro" la novela alcanza su punto climático y los elementos diseminados en la trama encuentran su desenlace.

Como he anticipado, María de Jesús se confiesa en la comisaría y denuncia la conducta de su nieto Marcos. Su intervención llena lagunas del relato. Por ejemplo, revela los motivos — que ya he señalado— por los cuales Marcos ve en Elsa a su madre, así como se detiene en varias muestras de su progresivo envilecimiento. Ya apreciaba en él comportamientos agresivos durante su infancia, que llega a ejemplificar. A su juicio, el nieto es malo por naturaleza y el tiempo no ha hecho sino potenciar esa faceta; se fundamenta para su explicación en motivos cristianos (Bioy 271).

La serie termina con el final de la persecución de Marcos a Bioy, que se relaciona con el desenlace de un secuestro que se venía proyectando desde tiempo atrás y ante el cual el texto ya se había pronunciado. En particular en "Dos", donde Humberto descubre el interés de Bioy y su banda por raptar a un empresario argentino radicado en Lima: Gattuso (Bioy 118-119). En "Cuatro", se asiste al encuentro entre los secuestradores y Gattuso, pero son más sus ejes temáticos. Uno de ellos es el asesinato de Humberto a manos de su superior, el capitán Mejía, sometido a Bioy (Bioy 270), aunque se trata de una acción próxima a todo lo que rodea a la persecución por sus nexos con la banda implicada en ella.

Aquí se cruzan las bandas de Bioy — con este a la cabeza—, Gattuso y Marcos, que seguía a Bioy. La acción es narrada desde un ángulo retrospectivo por

\footnotetext{
${ }^{15}$ A favor de la segmentación narrativa, notemos que una entrada en el blog, datada a 20 de febrero de 2008, da lugar a comentarios que se insertan desde días distintos, pero estos no se presentan en virtud del día: se muestra antes el del día 22 de febrero que el del 21 . Una prueba más de la necesaria colaboración del lector.
} 
un nuevo personaje, otra voz narrativa, que es un integrante de la banda, Héctor Mamani Vega, el Burro:

Todo salió mal..., hasta el Cholo llamó al repliegue cuando el Charly le disparó a la jerma... Cojudo de mierda... Matarla fue cosa de él... Su culpa... Se escapaba y disparó y el Cholo... El Cholo no se lo podía creer... Uno de los gorilas del viejo le vació la metraca y ahí quedó... El Charly... Yo estaba listo para irnos pero luego salió Bioy del auto y... Así no era, jefe, así no se había planeado pero al final fue bueno... En plena balacera, Bioy mató al gorila y al del volante y... Salvo el Charly, todos seguíamos vivos... Todo se arregló... Gattuso solo gritaba que no lo maten... Pensé que podíamos..., que la haríamos después de todo pero entonces... Ahí fue que apareció... El sicario, el de la cicatriz... Fue muy rápido, pensé incluso que eran los tombos, pero no había sirenas ni nada... Primero cayó el Cholo y, en menos de un segundo, Martillo... Yo me friqueé, retrocedí... Ni lo pensé... O me largo o me cagan, me dije... Bioy giró el cuerpo... Eso pude verlo... En ese momento llegó otro disparo pero desde dentro del auto... ¿Que quién fue? Fue Gattuso, ¿quién más?... Debía tener un arma, el viejo pendejo... Le dio a Bioy en el estómago... Y el sicario gritó... ¡El hijo de puta gritó como si Bioy fuera su hermano, imagínese!... La gente..., la gente se ha vuelto loca en este país, teniente...

A Gattuso lo mató él...

El sicario...

El resto ya no lo vi... (Bioy 293-294)

Como se comprenderá — aunque no se dice a las claras_, el "sicario" que dispara contra Gattuso no puede ser otro que Marcos, individualizado por su cicatriz, que se menciona en un punto anterior de la novela (Bioy 26). El motivo de su disparo - suponemos de nuevo - es que Gattuso se le ha adelantado en este ataque definitivo a Bioy; un modo de venganza. Acaba así Marcos con la vida de 
Gattuso. Pero Bioy vivirá un tramo más de la novela a raíz de su ingreso en un hospital, lugar en que agoniza ante la mirada de Marcos, que de nuevo consigue sortear los controles de seguridad y acceder hasta su habitación:

La realidad se desploma súbitamente, cabo Cáceres, y usted se muere junto al muchacho enfermo que le ha traído la desgracia. Ese monstruo, ese bastardo repugnante que se atrevió a matar al Cholo y a Martillo y al que habrías desollado sin el menor remordimiento, dice que te perdona y te llama "padre" y te irrita no entender nada de esa broma macabra, aunque también sientes miedo. Es comprensible. ¿Cómo entregarse ahora, cuando el pequeño y monótono mundo se ha vuelto laberinto y manicomio sin puertas, cuando la muerte te espera tranquila tras este último umbral del horror? Habría que escucharlo. De nada valen tus preguntas ni tus reclamos ni tus insultos porque Marcos — ese es su nombre - responde a todo con la misma sentencia: "Estás delirando, padre. Cálmate. Todo va a salir bien”. (Bioy 299)

Marcos, con la última muerte, finaliza el recorrido que se propuso. No cabe duda del éxito de la operación aunque la muerte de Bioy se diese en términos imprevistos. El joven consigue su cometido y se concede perdonar a Bioy; deducimos que por aquella violación. Es el modo en que Marcos obra justicia o, mejor dicho, obra lo que él comprende como justicia, venciendo al padre, sintiéndose superior a él.

Lo anterior se complementa con la confesión de María de Jesús en la comisaría, que genera una interesante alternancia que dista en un aspecto: frente a "Tres" — donde se explota la variedad de cauces narrativos, siempre titulados en función de estos-, la serie que involucra a Marcos y Bioy en "Cuatro" carece de título temático. Entonces, adopto para nombrarla la convención de "en torno al fallido secuestro". Los títulos en esta última se ciñen a motivos de hora, fecha y 
lugar, clave para extraer que Héctor Mamani Vega, el Burro, confesará en la misma comisaría donde lo hace María de Jesús. Veamos:

a) "Comisaría PNP-San Andrés-Barrios Altos. Jirón Huallaga cuadra 8. Cercado de Lima"

i) 10 del 15 de abril de 2008

ii) 10:20 del 15 de abril de 2008

iii) 10:30 del 15 de abril de 2008

iv) 10:45 del 15 de abril de 2008

v) 11:00 del 15 de abril de 2008

b) En torno al fallido secuestro
i) 4 del 5 de mayo de 2008
ii) $8: 35$ del 7 de mayo de 2008
iii) 9:28 del 5 de mayo de 2008
iv) $8: 00,8: 40$ y $8: 25$ del 7 de mayo de 2008
v) $8: 50,8: 55,9: 30,21: 40,9: 45$ y 10 del 7 de mayo de 208

vi) 1:30, 2, 2:40 y 3:15 del 9 de mayo de 2008

Enuncio los parámetros temporales de acuerdo con su orden de aparición en el texto, con lo cual realzo una vez más el desorden en que se presenta la materia narrativa, vertida en diversidad de convenciones formales además. Por caso, del segundo grupo - b) - iii) (5 de mayo) se intercala entre dos capítulos ambientados en otro día (7 de mayo): ii) y iv). Se pueden aducir más ejemplos de interés en torno al tiempo. Uno es que la confesión de María de Jesús en la comisaría resulta de importancia porque se desarrolla en solo una hora y se segmenta en momentos concretos, mecanismo con el cual se omiten elipsis densas, comunes en la novela. Otro, que, de b), iii) es relevante por aludir al asesinato del capitán Mejía, con lo cual se inspira en un tiempo diferente e interfiere en el ritmo o tempo de la novela, 
dado que interrumpe el relato de la persecución de Bioy y las confesiones de María de Jesús en la comisaría.

"Cuatro" en su propio eslabonamiento narrativo merecería un tratamiento por extenso. Aparte de los motivos anteriores, destaca que el tiempo vuelve a guiar la trama, como ocurría en "Uno", y así se instaura un fundamental eje de simetría que sirve para cerrar la novela, hasta el último capítulo, de título "2008", que depara la mencionada muerte de Bioy. No es un tiempo este que se espere del vaivén dado durante "Cuatro", pero conecta con los dos bloques generales de esta parte en un sentido temático, el cual converge en la figura del en su día joven cabo: "Enfermo, hambriento, delirante. Asqueado hasta la náusea por el olor de su propia mierda" (Bioy 298). Son las palabras que describían a Elsa en "Uno", antes citadas (Bioy 11). La conclusión conecta con el principio y se revive 1986 en 2008.

Pero el valor de "2008" no se agota en estos términos. Tras un continuo discurrir narrativo, el texto acoge un realce tipográfico en el tránsito a los últimos párrafos de la novela. En el primero se menciona la definitiva muerte de Bioy y descubrimos a un inesperado personaje, cuya importancia se extiende a la trama entera:

Y así llega el fin. Un hombre muere entre los brazos de otro. Ése es el fin o así me lo contaron. No hubo manera de saber qué pasó después. Si Marcos se marchó. Si le dio cristiana sepultura a Bioy. Si reclamó el cuerpo de Elsa. Si se voló la cabeza. Si sigue vivo, sobreviviendo como otro ciudadano más entre los modernos edificios de Lima. Si algún día pueda leer esta historia para negarla. Si algún día pueda mirarlo a los ojos y preguntarle si le gustó. No se sabe. No es lo importante. Así me lo dijeron y yo asentí y luego me quedé quieto y seguí bebiendo. Lo recuerdo ahora - que ya tengo otra vida - desde este pueblo frío y desangelado al norte de Nueva York. Lejos de casa. Lejos de un país que abraza ciegamente el progreso y donde ya nadie quiere escuchar historias como ésta. Tantas, 
tantísimas historias como ésta que hasta la mía parece mentira. Tantas fantasías. Tanta literatura para llegar al mismo punto de partida. (Bioy 300)

Este llega a referir, alterados, unos versos de César Vallejo, "el poeta peruano", de su poema "Los heraldos negros"16:

Pero entonces uno recuerda las sabias palabras del poeta peruano y la duda más oscura se empoza entre el corazón y la frente. Porque es el azar lo único permanente en la vida de los hombres, porque está escrito que en Lima todo es posible, señores, de buenas a primeras sucede una cosa, y sanseacabó... (Bioy 301)

Se manifiesta, en consecuencia, una voz que se realiza en un cuerpo más de la ficción, cuestión fundamental que retomaremos en el estudio de las voces narrativas. Lo cierto ahora es que esta voz se sitúa en el plano desde el cual se hilvana el relato entero, el cual cuenta con una dimensión temporal precisa cifrada en las últimas palabras de la novela: "New York, febrero, 2012" (Bioy 301). Es decir, se contrasta 1986 con 2002-2008 desde el presente, que se contextualiza en 2012. Los dos primeros tiempos dependen del último, o, dicho en otros términos, el pasado y el futuro del pasado — pasado para el presente - se someten a las coordenadas y a una voz que emana del estricto presente, que incluso se vincula con el tiempo de publicación real de Bioy, activando con ello un interesante procedimiento de confusión de la realidad y la ficción que habrá de tratarse, aun de pasada, en el siguiente apartado:

\footnotetext{
${ }^{16}$ Publicado en el libro homónimo (1919). Son los siguientes versos: "Y el hombre... Pobre... pobre! Vuelve los ojos como / cuando por sobre el hombro nos llama una palmada; / vuelve los ojos locos, y todo lo vivido / se empoza, como charco de culpa, en la mirada" (Vallejo 59).
} 


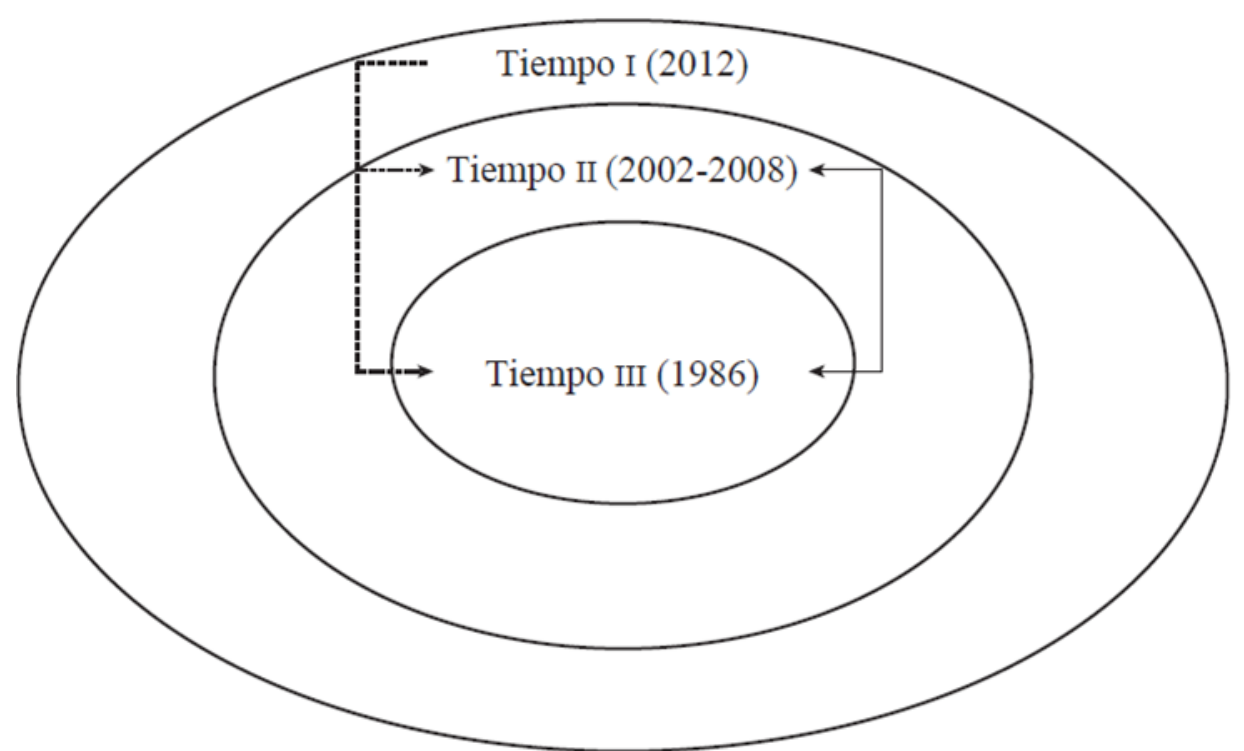

Fig. 1. Los tres tiempos de Bioy

El esquema representa el dominio (línea discontinua) y el contraste temporal (línea continua) de Bioy. En el dominio, el tiempo I ejerce control sobre los tiempos II y III, dado que el relato proviene de I. Se desarticula con la irrupción del último personaje y su tiempo la opción de comprender la voz que narra como omnisciente o abstracta, no sujeta a contingencias. Es este un personaje que fabula desde lo que le han contado, con lo cual Trelles Paz insiste en la memoria como forma de afrontar el presente y construir el futuro.

Al lado del dominio temporal, descuella el contraste de acuerdo con las interacciones que entran en dialéctica. Se enfatiza por esa vía la propagación de la violencia en el tiempo y la vorágine que puede producir. Sin afán exhaustivo, podemos recordar algunos acontecimientos de 1986 con consecuencia en 20022008:

a) El ingenuo cabo Cáceres termina transformándose en el violento Bioy.

b) Los cuatro violadores de Elsa son asesinados, incluido Bioy. 
c) Elsa, por aquella violación y otros sucesos traumáticos, se encuentra postrada en la cama de un hospital con un grave trastorno mental.

d) Marcos piensa que nació de aquella violación y que su padre sería Bioy, idea recurrente y que explica su comportamiento, aunque derive de un error.

Los cuatro ejemplos podrían crecer en número y siempre precisarían de una estrecha relación entre 1986 y 2002-2008 para ser interpretados. Estas dos décadas se enlazan en la continua violencia y la falta de autoridades oficiales que apacigüen el conflicto; lejos de hacerlo, lo agravan. Baste recordar que los cuatro violadores de Elsa forman parte del ejército peruano y que el capitán Mejía llega a asesinar a su subordinado Humberto. Se manifiesta así la desconfianza hacia los organismos estatales, a excepción de María de Jesús, que decide sincerarse en la comisaría a falta de otros recursos. Son personajes que se toman la justicia por su mano ${ }^{17}$.

Por último, ¿por qué Nueva York? ¿Por qué el relato dimana de Estados Unidos? El personaje subraya esa condición: "Lejos de casa” (Bioy 300), "Lejos de un país que abraza ciegamente el progreso y donde ya nadie quiere escuchar historias como esta" (Bioy 300). Es la voz de quien ha vivido en Perú -y se identifica con Perú - y conoce bien el fondo de Bioy. Pero se ve abocado a efectuar su relato desde el exterior, como si no tuviese cabida dentro de las fronteras peruanas, de las que sale y se abre a otras culturas y se forma cierta perspectiva, como hizo César Vallejo, lo cual explica su presencia en los últimos compases de la novela ${ }^{18}$. El motivo de la limitación de su país de origen, dice esta voz, es la fe

${ }^{17}$ La actitud de Marcos no se aísla del panorama de la más reciente narrativa policial o policíaca hispanoamericana. Véanse dos trabajos que Forero Quintero ha consagrado a lo que denomina "novela de crímenes" (La anomia y La novela de crímenes). Al respecto, ha desarrollado la noción de "anomia", propiciada por el motivo central del desorden social, que ha aplicado al ámbito latinoamericano en general. Los personajes suelen romper con los ordenamientos jurídicos y las normas a la hora de solventar sus propios conflictos, como se puede ejemplificar con Bioy.

${ }^{18}$ Se ha dicho del poeta peruano: "La mitología personal de César Vallejo no puede ser más propia. El cosmopolitismo de Vallejo no es el de quien se impone una escenografía citadina, una geografía poética que cambia de acuerdo a su entorno. La geografía en donde se mueven los temas de Vallejo 
en un progreso ciego; inferimos que no anclado convenientemente en la memoria. Conecta así el comentario de este personaje con lo que pretende Bioy: un ejercicio de memoria, para lo cual es necesaria la articulación de relatos como forma de procesar el pasado.

\section{Las voces narrativas}

Se hace necesario complementar el apartado anterior con el abordaje específico de las voces narrativas, que entiendo como instancias comunicativas con las cuales se transmite la realidad concreta de la ficción (véase Segre 21-30). Para ello, conviene partir de una tabla que recoge dos contenidos: el tiempo y las voces narrativas en relación con las partes de la novela y los capítulos. Funciona como síntesis del apartado anterior y apertura a este.

Solo dos notas previas a la tabla. Primero, es importante discernir entre los conceptos y los términos que utilizaré, en aras de la claridad expositiva y conceptual, dado que se emplean en una dirección específica ${ }^{19}$ :

a) Narrador externo (NE). Narrador que refiere la materia del relato sin participar o haber participado en ella.

b) Narrador interno (NI). Narrador que refiere la materia del relato participando o habiendo participado en ella.

no está supeditada, enmarcada en París o Trujillo, por España o Santiago de Chuco, esto es algo episódico, tal vez meramente accidental: la geografía cosmopolita de Vallejo se da en su arraigo, está trazada en un mapa de nómadas que dibuja la nueva ciudad, sin abandono de su profunda raigambre andina" (Roca 134).

${ }^{19}$ Para ello, sirven como fundamento las aportaciones del "estructuralismo francés", esenciales para el desarrollo de la narratología como disciplina o enfoque apegados a lo narrativo como objeto de estudio (véase Gómez Redondo 219-255). Para un balance general de las categorías que se pautaron sobre el narrador desde este movimiento teórico y crítico, véase, además de Gómez Redondo (219-255), por ejemplo, Segre (30-35). Utilizo, sin embargo, términos que se apartan de las formulaciones abstractas que se promovieron y que se ajustan a las específicas necesidades del presente estudio, resultando útiles para la explicación del hecho literario concreto, o al menos más útiles que otras categorías. 
CATEDRAL TomAdA: Revista de crítica literaria latinoamericana / Journal of Latin American Literary Criticism Violencia y multiplicidad narrativa en Bioy, de Diego Trelles Paz

c) Monólogo (M). Forma de expresión caracterizada por la intervención de una sola voz.

d) Diálogo (D). Forma de expresión caracterizada por la intervención de dos voces.

En segundo lugar, aprovecho la disposición tipográfica de los años sobre la tabla para denotar el vaivén de los capítulos — cuando exista—. Priorizo el lugar izquierdo sobre el derecho y dejo el centro para una tercera opción. Cuando el tiempo de un capítulo no forme parte de determinado sistema de alternancias, se ubicará a la izquierda sin ningún valor añadido.

Esta es:

\begin{tabular}{|c|c|c|}
\hline CAPÍtUlo & TIEMPO & $\begin{array}{c}\text { VOZ NARRA- } \\
\text { TIVA PRINCIPAL }\end{array}$ \\
\hline \multicolumn{3}{|c|}{ "Uno" (7 capítulos) } \\
\hline "1986" & 1986 & $\mathrm{NE}$ \\
\hline “2002” & 2002 & $\mathrm{NE}$ \\
\hline "1986" & 1986 & $\mathrm{NE}$ \\
\hline “2003” & 2003 & $\mathrm{NE}$ \\
\hline "1986" & 1986 & $\mathrm{NE}$ \\
\hline "2004" & 2004 & $\mathrm{NE}$ \\
\hline “1986" & 1986 & $\mathrm{NE}$ \\
\hline \multicolumn{3}{|c|}{ "Dos" (9 capítulos) } \\
\hline "I" & \multirow{8}{*}{$2007-2008$} & NI (Humberto) \\
\hline "2" & & NI (Humberto) \\
\hline "3" & & NI (Humberto) \\
\hline "4" & & NI (Humberto) \\
\hline "5" & & NI (Humberto) \\
\hline "6" & & NI (Humberto) \\
\hline "7" & & NI (Humberto) \\
\hline "8" & & NI (Humberto) \\
\hline "9" & 2008 & NI (Humberto) \\
\hline \multicolumn{3}{|c|}{ "Tres" (14 capítulos) } \\
\hline "La gente es fea" & 2008 & $\begin{array}{c}\mathrm{M} \\
\text { (Eme Zunz) }\end{array}$ \\
\hline "Hospital Víctor Larco Herrera" & 2003 & $\begin{array}{c}\mathrm{D} \\
\text { (Elsa y Marcos) }\end{array}$ \\
\hline "La gente es fea" & 2008 & $\mathrm{M}$ \\
\hline
\end{tabular}


CATEDRAL TOMADA: Revista literaria latinoamericana / Journal of Latin American Literary Criticism

Pedro Mármol Ávila

\begin{tabular}{|c|c|c|c|}
\hline & & & $\begin{array}{l}\text { (Diegoulasse el } \\
\text { Exterminador) }\end{array}$ \\
\hline "Hospital Víctor Larco Herrera" & & 2004 & $\begin{array}{c}\mathrm{D} \\
\text { (Elsa y Marcos) }\end{array}$ \\
\hline "La gente es fea" & 2008 & & $\begin{array}{c}\mathrm{M} \\
\text { (Damián el Joto) }\end{array}$ \\
\hline "Cuaderno de pensamientos y estrategias" & 2001 & & $\begin{array}{c}\mathrm{M} \\
(\mathrm{Marcos}) \\
\end{array}$ \\
\hline "La gente es fea" & 2008 & & $\begin{array}{c}\mathrm{M} \\
\text { (Diegoulasse el } \\
\text { Exterminador) } \\
\end{array}$ \\
\hline "Hospital Víctor Larco Herrera" & & 2007 & $\begin{array}{c}\mathrm{D} \\
\text { (Elsa y Marcos) }\end{array}$ \\
\hline "La gente es fea" & 2008 & & $\begin{array}{c}\mathrm{M} \\
\text { (Damián el Joto) }\end{array}$ \\
\hline "Hospital Víctor Larco Herrera" & & 2007 & $\begin{array}{c}\mathrm{D} \\
\text { (Elsa y Marcos) }\end{array}$ \\
\hline "La gente es fea" & 2008 & & $\begin{array}{c}\mathrm{M} \\
\text { (Diegoulasse el } \\
\text { Exterminador) } \\
\end{array}$ \\
\hline "Cuaderno de pensamientos y estrategias" & 2002 & & $\begin{array}{c}\mathrm{M} \\
(\mathrm{Marcos}) \\
\end{array}$ \\
\hline "Hospital Víctor Larco Herrera" & & 2008 & $\begin{array}{c}\mathrm{D} \\
\text { (Elsa y Marcos) }\end{array}$ \\
\hline "La gente es fea" & 2008 & & $\begin{array}{c}\mathrm{M} \\
(\text { Eme Zunz) }\end{array}$ \\
\hline \multicolumn{4}{|c|}{ “Cuatro" (12 capítulos) } \\
\hline $\begin{array}{l}\text { "Comisaría PNP-San Andrés-Barrios Altos. } \\
\text { Jirón Huallaga cuadra 8. Cercado de Lima" }\end{array}$ & 2008 & & $\begin{array}{c}\text { M } \\
\text { (María de Jesús) }\end{array}$ \\
\hline $\begin{array}{l}\text { "Avenida Principal Nueva Toledo, } \\
\text { Cieneguilla" }\end{array}$ & & 2008 & $\mathrm{NE}$ \\
\hline $\begin{array}{l}\text { "Comisaría PNP-San Andrés-Barrios Altos. } \\
\text { Jirón Huallaga cuadra 8. Cercado de Lima" }\end{array}$ & 2008 & & $\begin{array}{c}\text { M } \\
\text { (María de Jesús) }\end{array}$ \\
\hline $\begin{array}{l}\text { "Calle Los Ingenieros. Esquina con avenida } \\
\text { Jacarandá. Valle Hermoso, Monterrico" }\end{array}$ & & 2008 & $\mathrm{NE}$ \\
\hline $\begin{array}{l}\text { "Comisaría PNP-San Andrés-Barrios Altos. } \\
\text { Jirón Huallaga cuadra 8. Cercado de Lima" }\end{array}$ & 2008 & & $\begin{array}{c}\text { M } \\
\text { (María de Jesús) }\end{array}$ \\
\hline $\begin{array}{c}\text { "Jirón Teodoro Cárdenas. Altura de la } \\
\text { cuadra } 13 \text { de la avenida Petit Thouars. } \\
\text { Lince" }\end{array}$ & & 2008 & $\mathrm{NE}$ \\
\hline $\begin{array}{l}\text { "Comisaría PNP-San Andrés-Barrios Altos. } \\
\text { Jirón Huallaga cuadra 8. Cercado de Lima" }\end{array}$ & 2008 & & $\begin{array}{c}\text { M } \\
\text { (María de Jesús) }\end{array}$ \\
\hline $\begin{array}{l}\text { "Calle Emancipación, 155. Urbanización El } \\
\text { Derby. Monterrico, Santiago de Surco" }\end{array}$ & & 2008 & $\mathrm{NE}$ \\
\hline $\begin{array}{l}\text { "Calle Los Ingenieros. Esquina con avenida } \\
\text { Jacarandá. Valle Hermoso, Monterrico" }\end{array}$ & & 2008 & $\mathrm{NE}$ \\
\hline $\begin{array}{l}\text { "Comisaría PNP-San Andrés-Barrios Altos. } \\
\text { Jirón Huallaga cuadra 8. Cercado de Lima" }\end{array}$ & 2008 & & $\mathrm{M}$ \\
\hline
\end{tabular}




\begin{tabular}{|c|l|c|}
\hline & & $\begin{array}{c}\text { (Héctor Mamani } \\
\text { Vega, el Burro) }\end{array}$ \\
\hline $\begin{array}{c}\text { "Comisaría PNP-San Andrés-Barrios Altos. } \\
\text { Jirón Huallaga cuadra 8. Cercado de Lima" }\end{array}$ & 2008 & $\begin{array}{c}\text { M } \\
\text { (María de Jesús) }\end{array}$ \\
\hline "2008" & 2008 y 2012 & NE \\
\hline
\end{tabular}

Tabla 1. Los tiempos y las voces narrativas principales de las partes y los capítulos de Bioy

La tabla organiza elementos de diversa clase. Sobre el tiempo, una vez examinados sus rasgos con anterioridad, no añadiré nada directamente; solo cuando entronque con las voces narrativas. Y, en cuanto a ellas, tomamos el punto de referencia del desenlace, antes sintetizado y abordado desde la óptica del tiempo. Allí se halla el artífice - ficticio artífice- del relato, cuya intervención concede un nuevo sentido al libro entero. De las continuas novedades narrativas esta es la última, medida e inesperada audacia que arrebata a la novela el único asomo de objetividad que parecía contener. En efecto, la tercera persona narrativa que, con rigor, se había manejado durante la exposición del relato, al no decirse lo contrario, conducía a la tradicional conexión con un narrador ajeno por completo a la trama y que funciona como entidad abstracta, independiente de cualquier coyuntura del relato. El mecanismo se volvió fundamental en la narrativa del siglo XIX (Balzac, Zola, Pérez Galdós, Clarín, etc.), dado que cumplía con las necesidades de autores que buscaban una perspectiva concreta a la hora de enhebrar su discurso: una mirada omnisciente u omnímoda (Mainer 188) desde la que maniobrar con total libertad en la exposición del argumento narrativo y abrirse a multitud de posibilidades (desnudar a unos personajes y a otros, penetrar en su mundo interior, orientar la lectura, dialogar con el lector, etc.). Trelles Paz renuncia voluntariamente a estos modelos en pos de dinamitar cualquier unidad del texto, incluida la que puede afectar al foco desde el cual se dan a conocer las peripecias narrativas. Y también cualquier atisbo de aprehensión total de la realidad.

Trelles Paz se está relacionando con la tradición hispanoamericana que con mayor ahínco persiguió la novela total, como hace Bioy: la del boom (Gabriel García Márquez, Mario Vargas Llosa, Carlos Fuentes, etc.). Sin embargo, dista de ellos en la aspiración: no abarcar la realidad entera, no ofrecer una mirada global 
sobre nada, sino aquilatar una perspectiva sustanciada en el fragmento y en lo múltiple, ante una violencia que no se deja aprehender de modo unidimensional ${ }^{20}$.

La renuncia al narrador como entidad suprema conlleva el refuerzo del orden ficcional del texto, debido a que es interpretado y referido, enteramente, por personajes de ese mismo orden, aunque el narrador se mantenga externo a la acción. Gana ese mundo ficticio en relieve. Ahora bien, solo en relación con la incursión final del narrador, en virtud de la cual comparte el mundo de ficción con los personajes de su relato, apreciamos dos ideas centrales que vienen a reforzar este relieve:

a) La conexión de este personaje con el lector de la novela Bioy. El relato, al provenir de su punto de vista, conecta de modo especial con el lector, por cuanto logra este recibir el mensaje de un personaje que se encuentra inmerso en la trama. Es esta una implicación que se da cuando cualquier personaje se encarga de articular un relato, pero el mecanismo cobra especial relevancia por anunciarse en la conclusión. Además, como anticipé, no es solo que el personaje hable y el lector descubra detalles de su realidad, sino que se expresa en momentos cercanos al tiempo final de la novela. Tanto es así que esta acaba en el mencionado cronotopo de "New York, febrero, 2012". Se potencia así la cercanía de la trama al universo del lector y viene a poner de relieve la actualidad del conflicto que se aborda.

b) Las voces narrativas multiplican su profundidad. No es solo que otra voz se incorpore, sino que domina al conjunto; es el núcleo que vertebra el relato y contribuye con las demás voces a

\footnotetext{
${ }^{20}$ Véase Forero Quintero ("La novela total o la novela fragmentaria") sobre la novela total como ha sido comprendida y practicada por Mario Vargas Llosa, frente al modelo fragmentario impulsado por Macedonio Fernández. El contraste resulta elocuente, pues Bioy, aunque se asimila al modelo novelesco de Vargas Llosa, se desliza hacia propósitos fragmentarios en su fondo, en su razón de ser como texto literario. Véase también el clásico trabajo de Vargas Llosa sobre García Márquez.
} 
perfilarlo. Por tanto, está en el origen del texto y multiplica su perspectivismo, al convertir el relato en creación de un personaje de ficción sobre otros personajes de la misma esfera significativa. Son, por tanto, reales para él pero ficticios para los lectores, lo cual activa la interacción realidad-ficción como una clave más de la novela, así como el nexo que une a Trelles Paz con este personaje que irrumpe al final ${ }^{21}$.

Se reflejan los datos narrativos en un nuevo esquema, que requiere una explicación previa. Representa al autor real o empírico (A), Diego Trelles Paz, que a través de la apertura de un orden ficticio $(\mathrm{F})$ concede la primacía del relato a un personaje que funciona como artífice, su componedor (C), a tenor de cuatro sistemas de voces: por él mismo y desde su propia expresión (NE) o mediante el

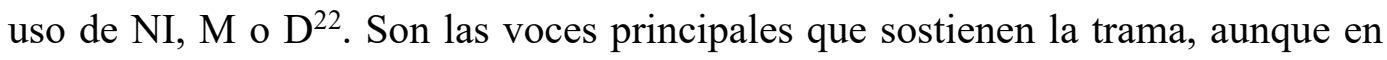
cada capítulo puedan rastrearse más tipos de expresión. El repertorio goza de variedad. Este es el esquema:

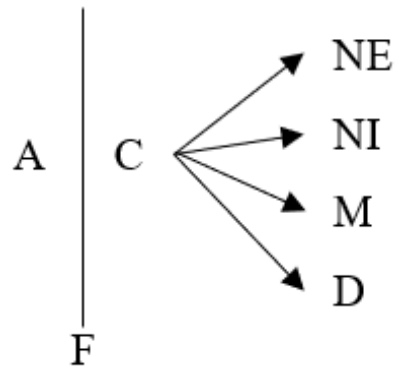

Fig. 2. Las voces narrativas de Bioy desde la instancia del autor real o empírico

El NE se ocupa de los hechos de 1986 y 2002-2004 de "Uno" y reaparece en "Cuatro" para clausurar la novela. Y no solo relata estos hechos; se define

\footnotetext{
${ }^{21}$ También es conflictiva la relación de Diego Trelles Paz con Perú y ha vivido bastantes años fuera de sus fronteras, por ejemplo. Para un breve apunte biográfico acerca de Trelles Paz, véase Almenara (nota 2).

${ }^{22}$ Ténganse en cuenta el desarrollo de cada sigla y las definiciones de cada término, expuestos antes.
} 
también en su peculiar carácter digresivo cuando inserta apreciaciones de interés cinematográfico con las que enjuicia lo que la novela plantea y cómo lo hace, como si buscase una expresión verbal que pudiese traducirse en película. Se debaten por ello cine y literatura en su discurso. Estas apostillas se encierran entre corchetes. Las hay breves - “[La cámara vuelve]” (Bioy 11) — y extensas:

[La idea es novedosa y permite observarlo todo, pero carece de verosimilitud. La lente arriba y la cámara de seguridad sin movimiento que sólo registra las acciones sin audio. Es una sofisticación gratuita. El ejército no actuaba así. El tono del encuadre es azulado y es difícil distinguir los rostros de los cuatro hombres. Vemos la fecha y el conteo ascendente de los números en la parte inferior del cuadro. Cuando los movimientos se ralentizan, cuando un desperfecto técnico hace aparecer las rayas intermitentes y la imagen se detiene por segundos, todo parece una recreación salvaje. La ambigüedad de su naturaleza, no obstante, genera en la platea - la que aún no abandona la sala - una sonrisa de terror nervioso que es difícil de controlar. Ninguno de ellos puede creer en serio que esa mujer esté siendo ultrajada con tanta brutalidad. Cuando el hombre que le penetra reduce la fuerza de sus embates y recula, las extremidades de la mujer ceden y su cuerpo maltrecho parece confirmar su deceso. Los cuatro hombres hablan o se gritan porque uno de ellos está agitando frenéticamente los brazos. El hombre que acaba de violar a la detenida levanta de pronto al más joven y lo empuja hacia el trapo humano que yace desnudo sobre la mesa. La escena interminable prosigue. Ninguno de los espectadores muestra su descontento.] (Bioy 64-65)

Con ello, la propia personalidad narrativa del componedor del texto, este personaje, se presenta múltiple. Un añadido a la multiplicidad de las voces narrativas, que en sí mismas poseen variedad. Se evita la monotonía a toda costa. 
No extrañará, así las cosas, que en secciones capitalizadas por un determinado narrador — pongamos el NE — la forma del diálogo — por caso— pueda extenderse a lo largo de varias páginas, como ocurre con las conversaciones de los militares en la sala de torturas de "Uno" (Bioy 39-43). Los personajes tejen un mosaico polifónico donde, si bien es cierto que despunta el narrador externo y el personaje a él asociado, otros muchos personajes toman la palabra.

Se da con frecuencia, incluso, el estilo indirecto libre ${ }^{23}$ como vía por la cual el narrador penetra en el pensamiento de los personajes y fusiona su expresión con la de ellos, con el resultado de que mediante su voz comunica su pensamiento y su lenguaje se impregna de ellos, como advierte Almenara: “... el narrador se contamina con el habla de los torturadores" (157). Busca el narrador un cierto objetivismo que haga que los personajes se presenten tal como son, sin mayor mediación de su parte. De ahí que se les ceda la voz con tanta frecuencia y que los propios pasajes capitalizados por el NE se llenen de intervenciones de múltiples orígenes. Los pensamientos y las voces de los personajes llegan a mezclarse unos con otros en el discurrir del NE: "El cabo, avergonzado, se incorpora: no cerrará los ojos, mayor, pero ella sabe que no la mira y ahora es su voz como un eco — no llores, yo ya estoy muerta, tú sigues vivo, ¿quién sufre más? -, pero él, terco, iluso, la levanta en vilo, le sigue hablando bajito, la echa a andar" (Bioy 12). Se entrecruzan aquí el cabo Cáceres y Elsa.

Ahora bien, como he advertido, la principal multiplicidad de las voces narrativas no dimana de la propia caracterización e intervención de la voz nuclear, sino de su silencio durante notables dosis del relato en aras de otras voces que copan el primer plano y vehiculan capítulos enteros sin mayor mediación que su propia voz. Estos personajes adquieren relevancia como seres de una cierta autonomía y

\footnotetext{
${ }^{23}$ Para delimitar a qué me refiero con "estilo indirecto libre", aunque lo utilizaré sin desvíos con respecto a su uso convencional, destaco el siguiente comentario, relativo a sus consecuencias: "Otra cosa distinta es, en cambio, que el narrador cuente tratando de asumir la conciencia, y aun, en muchos casos, el lenguaje presunto del personaje, acercándose a él lo más posible —aunque sin prestarle la palabra. Hay aquí un debilitamiento de la voz narradora, tenemos la impresión de estar oyendo a los personajes" (Tacca 81).
} 
cada uno, en el fondo, viene a desplegar una determinada perspectiva sobre la realidad que traduce una personalidad compleja, a través de sus voces ${ }^{24}$.

En consecuencia, después del fundamental papel del NE en "Uno", el NI en "Dos" se ocupará de hacer lo que antes correspondía a NE, vertebrando la trama desde su exposición. Es este cargo asumido por Humberto Rosendo Hernández, cuyos ojos nos abren un modo distinto de articular la materia narrativa. El contraste es abierto y elocuente: la vista a vuelo de pájaro cede el testigo a la vista desde el ángulo de un personaje partícipe de los acontecimientos. En "Uno" el cabo Cáceres es referido de modo externo; en "Dos" se le verá en la distancia corta gracias al agente.

Tanto en "Uno" como en "Dos" actúan voces que gozan de continuidad durante las dos partes. Esta tendencia, sin embargo, se subvierte en "Tres" y "Cuatro", lo cual provoca una nueva variación narrativa nacida de un contraste que vuelve a poner de relieve los distintos modos de contar el horror y la violencia. En "Tres" y "Cuatro", las voces hablan sin ningún introductor o moderador externo, tal como es característico del cine o del teatro. En "Cuatro" también se manifiesta el NE, pero no introduce a María de Jesús cuando se confiesa en la comisaría ni a Héctor Mamani Vega, el Burro. La apertura a la expresión de los personajes resulta tan marcada que un personaje totalmente secundario, como este último, puede poner la suya en primer plano sin mediación alguna. Los seres del universo de ficción de Bioy buscan expresarse por sí mismos.

"Tres" cuenta con la particularidad de aglutinar una especial diseminación de voces. Su división en las consignadas tres secciones, o grupos de capítulos, favorece esta diseminación, pero se incrementa en el blog La gente es fea. Antes sugería lo que será constante, el movimiento entre dos estratos: a) las entradas del blog y b) los comentarios. Los segundos pueden provenir de los otros blogueros involucrados en el proyecto - que resultan ser todos ellos Marcos, como ya he aclarado- o hasta de aludidos, que responden a los insultos mediante sus

\footnotetext{
${ }^{24}$ Se advierte el concepto de "polifonía" de Bajtín como idea de fondo de este planteamiento.
} 
identidades virtuales. La confusión se genera y se proyecta, entonces, sobre estas voces y estos modos de intervenir en la Red. El caso es aprovechado incluso para trazar puentes con alguna otra obra de Diego Trelles Paz y dar la idea de que todo proviene del mismo mundo narrativo, en una suerte de continuidad en la ficción. Entreteje así Trelles Paz los hilos de sus textos. Un ejemplo es Larrita, nombrado por Diegoulasse el Exterminador: llega a reaccionar por medio de algún comentario en el blog. Es Larrita un personaje de otra novela de Diego Trelles Paz: El círculo de los escritores asesinos (2005). Lo mismo ocurre con Miguel Lautaro García Ordóñez, de esa novela también ${ }^{25}$.

"Cuatro" alberga iguales dosis de multiplicidad en cuanto a las voces narrativas, si no mayores. Aquí resultan especialmente productivas las alternancias que se suceden en el cauce del monólogo y que afectan a los personajes de María de Jesús y Héctor Mamani Vega, el Burro, si bien también participa el NE, que muestra detalles del secuestro ideado por la banda de Bioy y sus secuelas o del asesinato de Mejía. Finalmente, el golpe de efecto con el cual descubrimos que la narración entera deriva de la mirada de un personaje de ficción informado por otro personaje o varios, sea quien sea, sean quienes sean.

Es este un relato que recoge un concreto - ficticio- conflicto que pretende ser representativo de la sociedad peruana y que, en el tránsito de unos personajes a otros, de unas perspectivas a otras, de unas voces a otras, no hace sino adquirir relieve como significativo de esa sociedad y su tiempo. La intención última es que, en la ficción, pase por absolutamente cierto. El narrador, de hecho, calla en el punto en que le dejaron el relato, advirtiendo así de que se ha ceñido a lo que le comunicaron y que su narración, en consecuencia, estaría lo más aferrada posible a

${ }^{25}$ Tanto Larrita como Miguel Lautaro García Ordóñez, aparte de arrastrar matices literarios por su origen en otra novela del propio Trelles Paz, ya en sus propios nombres denotan mayor profundidad en este sentido, al derivar de la tradición literaria española: Mariano José de Larra, importante escritor romántico, y el conde García Ordóñez o Garci Ordóñez, personaje del Cantar de mio Cid y también personaje histórico. La onomástica resulta de especial vitalidad para Trelles Paz. Sin ir más lejos, el nombre de la novela, que coincide con el de su protagonista, proceden del nombre de un importante autor argentino: Adolfo Bioy Casares, al cual se rinde tributo (Trelles Paz “Diego Trelles Paz"). Este último resuena, incluso, en el apellido de Bioy: Cáceres. 
los hechos tal como fueron. Es una forma, pues, de suscitar verdades incompletas, complementarias, sujetas a contingencia. El relato como manera de enfrentarse a la violencia, al decirla, al narrarla.

\section{Conclusiones}

La violencia en Perú de finales del siglo XX y comienzos del XXI constituye el eje temático esencial de Bioy, novela donde esta es aprehendida de modo específico: recurriendo a la multiplicidad narrativa. Este principio se aprecia en los dos ejes que se han estudiado: el tiempo y las voces del relato. Del primero destaca el movimiento entre el pasado (1986) y el futuro de ese pasado (20022008), que es también pasado del momento en que se enuncia el relato: el presente (2012). En ese movimiento se observa un claro intento de descomponer cualquier atisbo de unidad temporal. Pero hay otro principio de descomposición en el foco del relato: no es una sola voz la cual marca el ritmo de la trama; son múltiples. En este sentido, se han puesto de relieve los cuatro sistemas empleados para eslabonar los elementos narrativos de los capítulos: el narrador externo, el narrador interno, el monólogo y el diálogo. Colaboran y se complementan unos con otros para dar con la multiplicidad narrativa también en esta dimensión como clave del relato. El fin no es otro que el de llamar la atención sobre la complejidad de la violencia que se analiza y, por ende, de la realidad peruana entera, que se escapa a miradas únicas o totalizadoras. El relato viene a ser un poliedro con inmensidad de caras que van en la dirección de abrir lo múltiple como forma de interpretación. La violencia, por todo ello, es abordada desde variedad de ángulos y se acaba mostrando su imparable desarrollo a partir de los sucesos que la motivaron, inscritos en las actividades de Sendero Luminoso décadas atrás. 
CATEDRAL TOMADA: Revista de crítica literaria latinoamericana / Journal of Latin American Literary Criticism Violencia y multiplicidad narrativa en Bioy, de Diego Trelles Paz

\section{Bibliografía}

Almenara, Erika. "Descomposición de la masculinidad peruana en Bioy de Diego Trelles Paz". Revista Iberoamericana, n. ${ }^{\circ}$ 262, 2018, pp. 153-166. Impreso.

Amar Sánchez, Ana María. "Narrar desde la violencia del perdedor”. Literatura y violencia en la narrativa latinoamericana reciente, ed. de Teresa Basile, La Plata, Universidad Nacional de La Plata, 2015, pp. 65-85. Impreso.

Bajtín, Mijaíl. Problemas de la poética de Dostoievski, trad. e índices de Tatiana Bubnova, introd., bibliografía, cronología y revisión de Tatiana Bubnova y Jorge Alcázar. 3. ${ }^{\mathrm{a}}$ ed. México, Fondo de Cultura Económica, 2012. Impreso.

Comisión de la Verdad y Reconciliación. “Informe final”. 2003. En línea: http://cverdad.org.pe/ifinal/ [8 de junio de 2018].

Cuya Gavilano, Lorena. "Internal Migration, the Publishing Industry, and Transnational Identities in Two Peruvian Writers". Revista Hispánica Moderna, vol. 69, n. ${ }^{\text {1 }}$ 1, 2016, pp. 1-16. Impreso.

Degregori, Carlos Iván. El surgimiento de Sendero Luminoso. Ayacucho 19691979. Lima, Instituto de Estudios Peruanos, 1990. Impreso.

ElCultural.es. "El peruano Diego Trelles gana el Premio de Novela Francisco Casavella 2012”. El Cultural, 16 de julio de 2012. En línea: https://www.elcultural.com/noticiaimp.aspx?idnoticia=3471 [8 de junio de 2018].

Forero Quintero, Gustavo. "La novela total o la novela fragmentaria en América Latina y los discursos de globalización y localización”. Acta Literaria, n. ${ }^{\text {4 }}$ 2, 2011, pp. 33-44. Impreso. . La anomia en la novela de crímenes de Colombia. Bogotá, Siglo del Hombre Editores, 2012. Impreso. . La novela de crímenes en América Latina: un espacio de anomia social. Bogotá, Siglo del Hombre Editores, 2017. Impreso. 
Gnutzmann, Rita. "Cine y novela sobre los años de violencia peruana". Letral, n. ${ }^{\circ}$ 3, 2009, pp. 69-82. En línea: http://revistaseug.ugr.es/index.php/letral/article/view/3575 [8 de junio de 2018].

. "Una retrospectiva sobre medio siglo de narrativa peruana". América sin Nombre, n. ${ }^{\circ} 13-14,2009$, pp. 192-202. Impreso.

Gocławska, Aleksandra. "¿Representación como una forma de violencia? Psicoanálisis y desigualdad en la novela Bioy de Diego Trelles Paz". Violencia y discurso en el mundo hispánico. Género, cotidianidad y poder, ed. de Miguel Carrera Garrido y Mariola Pietrak. Sevilla, Universidad Maria Curie-Skłodowska de Lublin/Padilla Libros Editores y Libreros, 2015, pp. 47-62. Impreso.

Gómez Redondo, Fernando. Manual de crítica literaria contemporánea. Madrid, Castalia, 2008. Impreso.

Llano, Aymará de. "Senderos iluminados. Mito y violencia en la novela peruana contemporánea”. Pilquen. Sección Ciencias Sociales, n. ${ }^{\circ}$ 16, suplemento especial, 2013, pp. 1-8. En línea:

http://revele.uncoma.edu.ar/htdoc/revele/index.php/Sociales/article/view/ 1452 [8 de junio de 2018].

Mainer, José-Carlos. La escritura desatada. El mundo de las novelas. Madrid, Temas de Hoy. 2000. Impreso.

Morales Muñoz, Brenda. "Bioy: violencia contra los cuerpos femeninos durante la lucha antisubversiva peruana”. La Colmena, n. ${ }^{\circ}$ 99, 2018, pp. 7-18. Impreso.

Noemí, Daniel. "Para una genealogía de la narrativa peruana reciente (escribir después del terror)". Letral, n. ${ }^{\circ} 3$, 2009, pp. 41-53. En línea: http://revistaseug.ugr.es/index.php/letral/article/view/3584 [8 de junio de 2018].

Ríos, Jerónimo, y Sánchez, Marté. Breve historia de Sendero Luminoso. Madrid, Los Libros de la Catarata, 2018. Impreso. 
Roca, Juan Manuel. Cartógrafa memoria (Ensayos en torno a la poesía).

Medellín, Universidad EAFIT, 2003. Impreso.

Segre, Cesare. Principios de análisis del texto literario, trad. de María Pardo de Santayana. Barcelona, Crítica, 1985. Impreso.

Sourp, Claire. Mario Vargas Llosa. Une écriture de la violence. Rennes, Presses Universitaires de Rennes, 2013. Impreso.

Tacca, Óscar. Las voces de la novela. 3. ${ }^{\mathrm{a}}$ ed. Madrid, Gredos, 1985. Impreso.

Trelles Paz, Diego. Bioy. Barcelona, Destino, 2012. Impreso.

. “Diego Trelles Paz: «'La literatura es una especie de maldición’».

Entrevista de Jaime Cabrera Junco y Marlon Aquino Ramírez. Lee por

Gusto, 16 de octubre de 2012. En línea:

http://www.leeporgusto.com/diego_trelles_la_literatura_es/ [8 de junio de 2018].

. "Bioy o la escritura como condición límite". Senderos de violencia.

Latinoamérica y sus narrativas armadas, ed. de Oswaldo Estrada.

Valencia, Albatros, 2015, pp. 177-183. Impreso.

Vallejo, César. Los heraldos negros, introd. de Efraín Kristal y ed. de Marta Ortiz Canseco. Madrid, Castalia, 2009. Impreso.

Vargas Llosa, Mario. García Márquez: historia de un deicidio. Barcelona, Barral, 1971. Impreso.

Vivanco, Lucero de. "Postapocalipsis en los Andes. Violencia política y representación en la literatura peruana reciente". Taller de Letras, n. $^{\circ} 52$, 2013, pp. 135-151. Impreso.

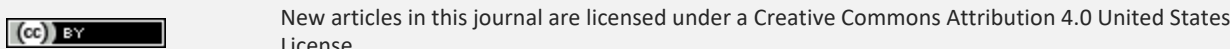
License.

ULLS D-Senfe This site is published by the University Library System, University of Pittsburgh as part of its D-Scribe Digital Publishing Program and is cosponsored by the University of Pittsburgh Press. 